\title{
Consolidated drained (CID) behavior of fibre reinforced cemented Toyoura sand in triaxial loading conditions
}

\author{
Muhammad Safdar ${ }^{1 *}$, Tim Newson $^{2}$ and Faheem Shah ${ }^{1}$
}

\author{
${ }^{*}$ Correspondence: \\ drsafdar@uetpeshawar.edu.pk \\ 1 Earthquake Engineering \\ Center, Department \\ of Civil Engineering, \\ University of Engineering \\ and Technology Peshawar, \\ Peshawar, Pakistan \\ Full list of author information \\ is available at the end of the \\ article
}

\begin{abstract}
The effects of fibre (0-3\%) and cement (0-3\%) additives, on Toyoura sand were examined under consolidated drained compression and extension loading conditions. All samples were prepared to a target dry density value (e.g., $\rho_{d}=1.489 \mathrm{~g} / \mathrm{cm}^{3}$ ) of Toyoura sand using under-compaction moist tamping technique. In compression, the unreinforced specimens exhibited a behavior of medium dense sand and reached a peak deviator stress $\left(q_{p}\right)$ at approximately $4 \%$ axial strain $\left(\epsilon_{a}\right)$ for the varying mean effective stresses, $p^{\prime}$ (i.e. 50-400 kPa). The peak drained strength increases in fibre reinforced cemented specimens were found to be up to 132\% (lower effective stresses) and $243 \%$ (higher effective stresses), while, the drained strength increases at critical state for the fibre reinforced cemented specimens were found to be up to $105 \%$ (lower effective stresses) and 245\% (higher effective stresses). Overall, the fibre and cement additives increased the stiffness, peak and strength at critical state of pure Toyoura sand but were found to be least effective in extension loading. Moreover, the stress ratio, peak and critical state stress ratios increase with the addition of fibres and cement. The secant modulus shows limited increases for the fibre reinforced specimens. However, a significant improvement in the secant modulus is observed for the fibre reinforced cemented specimens. For both unreinforced and reinforced specimens there is a decrease in volumetric strain with greater effective stresses or in other words, the rate of dilation decreases with increases in effective stresses. The fibre and cement additives also increased the strength parameters (frictional angle, cohesion), dilatancy angle, slope of the critical state line, and decreased the state parameter of pure Toyoura sand.
\end{abstract}

Keywords: Fibre reinforced sand, Drained behavior, Triaxial test, Dilatancy, State parameter, Critical state

\section{Introduction}

Mixing sand with randomly orientated discrete flexible fibres is found to most effectively enhance the strength and influence the deformation characteristics. The addition of fibres up to a concentration of $2 \%$ by mass can improve soil shear strength, but above this threshold fibres tend to increase the soil porosity and negate the strength increase [1]. Fibres mainly offer their contribution when subjected to tension and the orientation of the fibres within a specimen is therefore found to be particularly important for the

(c) The Author(s), 2021. Open Access This article is licensed under a Creative Commons Attribution 4.0 International License, which permits use, sharing, adaptation, distribution and reproduction in any medium or format, as long as you give appropriate credit to the original author(s) and the source, provide a link to the Creative Commons licence, and indicate if changes were made. The images or other third party material in this article are included in the article's Creative Commons licence, unless indicated otherwise in a credit line to the material. If material is not included in the article's Creative Commons licence and your intended use is not permitted by statutory regulation or exceeds the permitted use, you will need to obtain permission directly from the copyright holder. To view a copy of this licence, visit http:// creativecommons.org/licenses/by/4.0/. 
strength of reinforced soils [2]. Fibres are in general most influential when orientated in the same direction as the tensile strains [3]. Fibres that contribute most to strength are those with an orientation in the direction of maximum specimen extension [2, 4, 5]. The random fibre orientation has been deemed most effective as it will not create planes of weakness in the sample during shearing [6]. As the soil-fibre mixture deforms, the straining of the soil generates different stresses in the different fibres [7]. In terms of post-peak behavior, there is a consensus that the addition of fibres to soil reduces the loss in post-peak strength $[1,8,9]$ but has the effect of increasing the amount of volumetric compression at rupture $[10,11]$. The higher the fibre content, the larger the volumetric deformation found $[12,13]$. At high confining stresses, the compressive strength of reinforced sand appears to increase linearly with the concentration of fibres (the fibre concentration is conveniently expressed in terms of weight or volume fraction of dry sand); for low confining stress, this increase approaches up to an asymptotic upper limit $[1,8,14]$. In addition, the strength improvement at failure is linked with the fibre length: the longer the fibres the larger the strength increases [4, 15-17]. When fibres are stretc. hed, the mobilized tensile stress in the fibres is zero at their ends and increases towards the fibre centre $[2,5,14,18]$. Longer fibres may accumulate enough strains to allow the tensile strength of the fibres to be reached, while shorter fibres would simply slide through the sand particles before the fibre strength is reached [3]. Indeed, the portion of the fibres where the tensile strength is fully mobilised increases with the length of the fibres itself. However, there seems to be a limit to the length of fibres beyond which any further increase in length has no effect on the shear strength. The length of the fibres should be at least one order of magnitude greater than the size of the grains for achieving an effective fibre-sand interaction [19]. Subsequently, more detailed studies on soils reinforced with various kinds of fibre inclusion (e.g. polypropylene fibre, polyvinyl alcohol fibre, nylon fibre, polyester fibre, rubber fibre, plastic glass) have been performed by other researchers $[6,12,17,20-40]$ who successfully demonstrated the effectiveness of different fibre additives in soil improvement.

Diambra et al. [36] reported (Fig. 1a) the typical deviator stress-shear strain data for unreinforced and reinforced specimens with different fibre concentrations under triaxial compression conditions. The initial stiffness of the composite soil was not influenced by the presence of the fibres and the increased mobilized strength induced by the addition of fibres was significant and highly dependent on the fibre content (e.g., 0-0.6\%). The fibres inclusion did not affect the initial tangent stiffness of the sand specimens. The observation is consistent with the conclusions of Ranjan et al. [8] Consoli et al. [29] and Michalowski and Cermak [19]. It can also be seen that, there is negligible increase in mobilized strength in triaxial extension. Diambra et al. [34] demonstrated that the preferred horizontal bedding of fibres or fibre orientation induced by the moist tamping technique can be considered responsible for this limited increase in extension loading conditions. In the volumetric plane (see Fig. 1b), the contractive behavior of the unreinforced sample becomes more dilative when fibres are added for both compression and extension conditions. Furthermore, it may be expected that pronounced tensile contribution of the fibres would provide increased matrix confinement and in turn more contractive response [36, 41]. Consoli et al. [29], and Michalowski and Zhao [42] demonstrated that the inclusion of fibres inhibited the dilation of sand in triaxial tests. 

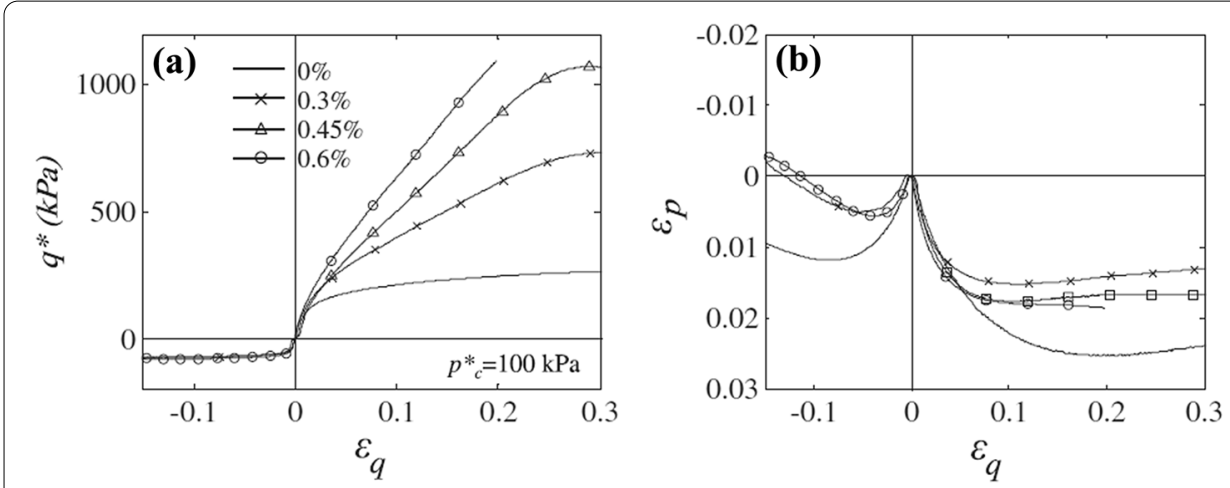

Fig. 1 a Deviator stress-shear strain and $\mathbf{b}$ Volumetric strain-shear strain response for drained triaxial tests on unreinforced and reinforced samples with different fibre percentages, isotropically consolidated to $100 \mathrm{kPa}$ [36]

Based on plate load tests results, Consoli et al. [31] also deduced that the fibres suppress the sand dilation. However, Ibraim and Fourmont [43], and Diambra et al. [34] reported that fibre-reinforced sand exhibited higher dilation tendency than unreinforced sand. In addition, Eldesouky et al. [44] reported that the maximum dilation angle of the dry siliceous sand specimens increased by about $10^{\circ}$ when the fibres content was increased from 0.0 to $1.0 \%$. The same effect was encountered when the relative density was increased from 25 to $90 \%$. Moist specimens had lower maximum dilation angle values than corresponding dry ones. Previous studies did not reveal a consistent trend with respect to the effect of randomly distributed fibres on the volumetric change behavior of fibre-reinforced sand. Thus, additional laboratory investigations should be further considered to explain the experimentally observed dilation [36], limited increase in initial stiffness, and several other parameters discussed in these sections.

Artificial cementation of granular soils results in an increase of stiffness and peak strength [45] associated with a more dilative response [46] and a pronounced post-peak brittleness [47]. Cementation also gives rise to some tensile strength [45]. Maher and Ho, [48] also stated that, cement increases the volumetric stability, and increases the liquefaction resistance in sandy soils. Clough et al. [45] suggested that the nature and amount of cement, confining stress, density, gradation, and structure are the governing variables. In addition, Gens and Nova [49] stated that soil behavior is affected by geological and stress-strain history, and also depends on strain rate, temperature, and principal stress direction. Other works pointed out the importance of the load rate [45], the stress path [50], microstructure, and inter-particle bonds [51] for cemented soil behavior.

As brittleness of soil increases with increasing cement content, sudden brittle failure might occur without plastic deformation. Fibres are therefore used to reduce the brittleness of cemented soils [52]. A number of studies have reported the combined effect of cement and fibre on the mechanical behavior of sandy soils $[6,40,53]$. Soil-cementfibre shows a complex behavior that is affected by many factors, for example the physical-chemical properties of the soil, fibre characteristics, the amount of cement, and the porosity and moisture content at the time of compaction [17, 31, 45, 54]. The literature review investigating fibre reinforced cemented sands have focused almost exclusively on higher cement content (e.g., greater than $3 \%$ ) and longer curing duration (e.g. greater 
than 3 days). Limited studies were reported for shorter curing duration (e.g., 3 days) and lower cement content (e.g. $0-3 \%$ by dry mass of soil). Short curing duration and lower cement content, which are close to the field shallow mixing technique, might help geotechnical engineers in the determination of minimum strength of composite materials. In addition, the previous research on fibre reinforced cemented sand also focuses on the determination of shear strength parameters and sand-fibre-cement matrix behavior in triaxial compression only. Therefore, fibre reinforced cemented soil composites require further investigation in extension loading conditions.

\section{Tested materials}

Three different types of material (e.g. Toyoura sand, polyvinyl alcohol (PVA) fibres, ordinary Portland cement $(\mathrm{OPC})$ ) have been employed in this study. Toyoura sand is a Japanese benchmark sand, which is a well-known laboratory test sand. The particles have a uniformity coefficient $\left(C_{u}\right)$ of 1.24 , a minimum void ratio $\left(e_{\text {min }}\right)$ of 0.62 , a maximum void ratio $\left(e_{\max }\right)$ of 0.95 , and a specific gravity of 2.65 . The grain size distribution of pure Toyoura sand is presented in Fig. 2a. Toyoura sand has been described as an angular to subangular, fine grained and poorly graded sand, which is confirmed by a low coefficient of uniformity and coefficient of curvature, according to the classification of SP by the Unified Soil Classification System (USCS). Microscopically, Toyoura sand can be clearly seen to be angular to sub-angular and fairly uniform in size $[6,40]$.

Synthetic monofilament polyvinyl alcohol (PVA) fibres as shown in Fig. $2 \mathrm{~b}$ have been used as fibre inclusions and reinforcing material in this research study. PVA fibres have been found to have superior chemical resistance, weather resistance, and tensile strength synthetic than propylene fibres. Therefore, the inclusion of PVA fibre produces more effective reinforcement in terms of strength and ductility, when compared to other fibres under the same cementation volumes [52]. Polyvinyl alcohol (PVA) fibres have a specific gravity of 1.3. Nominal dimensions of the individual fibres are $12 \mathrm{~mm}$ long and a diameter of $0.11 \mathrm{~mm}[6,40]$. The fibres have a Young's Modulus of $28 \mathrm{GPa}$ and a tensile strength of $1200 \mathrm{MPa}$ (Kuraray Cooperation Limited, Japan).

Ordinary Portland Cement Type-I (OPC-I) shipped from Ube-Mitsubishi Cement Corporation in Japan has been used as a cementing material and added as a percent by mass in each specimen. OPC-I has a specific gravity of 3.15 and a composition consisting of approximately $63 \%$ tricalcium silicate, $12 \%$ di-calcium silicate, $5 \%$ tri-calcium aluminate, $11 \%$ tetra-calcium alumino-ferrite [55]. These cement and fibre additives have

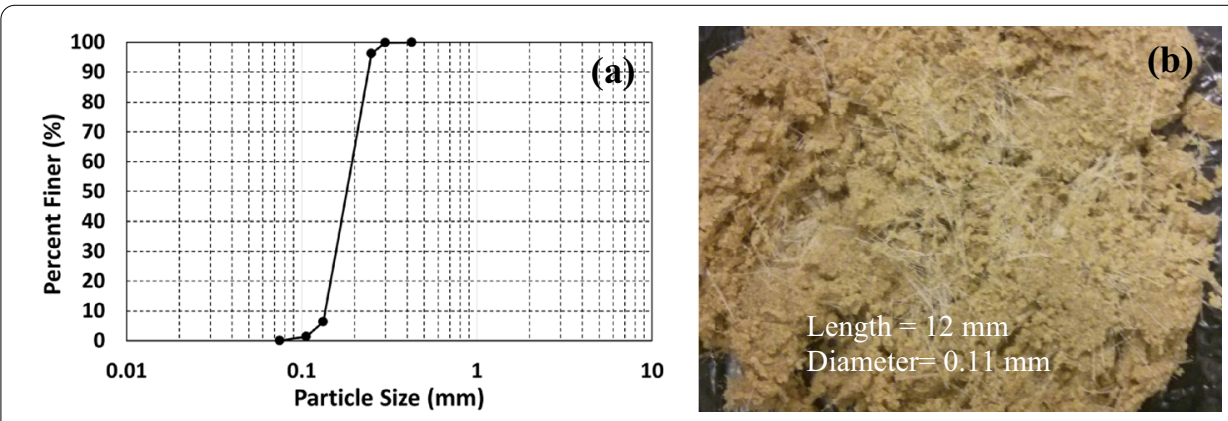

Fig. 2 a Grain size distribution curve for Toyoura sand $\mathbf{b}$ PVA Fibres 
Table. 1 Testing program for consolidated drained (CID) compression tests (Current study)

\begin{tabular}{|c|c|c|c|c|c|c|c|}
\hline Test No. & Test ID & $\begin{array}{l}\text { Mean effective } \\
\text { stress }\left(p^{\prime}\right)(\mathrm{kPa})\end{array}$ & $\begin{array}{l}\text { Cement } \\
\text { content } \\
(\%)\end{array}$ & $\begin{array}{l}\text { Fibres } \\
\text { content } \\
(\%)\end{array}$ & $\begin{array}{l}\text { Silt } \\
\text { content } \\
(\%)\end{array}$ & Lab & Test type $\mathrm{C} / \mathrm{E}$ \\
\hline \multicolumn{8}{|c|}{ Pure sand } \\
\hline 1. & CD-COFOMO-50 & 50 & 0 & 0 & 0 & WM & C \\
\hline 2. & CD-COFOMO-100 & 100 & 0 & 0 & 0 & WM & C \\
\hline 3. & CD-COFOMO-200 & 200 & 0 & 0 & 0 & WM & C \\
\hline 4. & CD-COFOMO-400 & 400 & 0 & 0 & 0 & WM & C \\
\hline \multicolumn{8}{|c|}{ Cement only } \\
\hline 5. & CD-C3FOMO-100 & 100 & 3 & 0 & 0 & WM & C \\
\hline \multicolumn{8}{|c|}{ Fibre only } \\
\hline 6. & CD-COF1M0-50 & 50 & 0 & 1 & 0 & WM & C \\
\hline 7. & CD-COF0.5M0-100 & 100 & 0 & 0.5 & 0 & WM & C \\
\hline 8. & CD-COF1M0-100 & 100 & 0 & 1 & 0 & WM & C \\
\hline 9. & CD-COF1M0-200 & 200 & 0 & 1 & 0 & WM & C \\
\hline 10. & CD-COF1M0-400 & 400 & 0 & 1 & 0 & WM & C \\
\hline 11. & CD-COF3MO-50 & 50 & 0 & 3 & 0 & WM & C \\
\hline 12. & CD-COF3M0-100 & 100 & 0 & 3 & 0 & WM & C \\
\hline 13. & CD-COF3MO-200 & 200 & 0 & 3 & 0 & WM & C \\
\hline 14. & CD-COF3M0-400 & 400 & 0 & 3 & 0 & WM & C \\
\hline \multicolumn{8}{|c|}{ Cement and fibre } \\
\hline 15. & CD-C3F1M0-50 & 50 & 3 & 1 & 0 & WM & C \\
\hline 16. & CD-C3F0.5 M-100 & 100 & 3 & 0.5 & 0 & WM & C \\
\hline 17. & CD-C3F1M0-100 & 100 & 3 & 1 & 0 & WM & C \\
\hline 18. & CD-C3F2M-100 & 100 & 3 & 2 & 0 & WM & C \\
\hline 19. & CD-C3F1M0-200 & 200 & 3 & 1 & 0 & WM & C \\
\hline 20. & CD-C3F1M0-400 & 400 & 3 & 1 & 0 & WM & C \\
\hline 21. & CD-C3F3M0-50 & 50 & 3 & 3 & 0 & WM & C \\
\hline 22. & CD-C3F3M0-100 & 100 & 3 & 3 & 0 & WM & C \\
\hline 23. & CD-C3F3M0-200 & 200 & 3 & 3 & 0 & WM & C \\
\hline 24. & CD-C3F3M0-400 & 400 & 3 & 3 & 0 & WM & C \\
\hline
\end{tabular}

C Compression and $E$ Extension

WM Test performed at Western University in current study, FU Fukuoka University

CID-COFOMO-50 Isotropically consolidated Drained test, Cement, $\mathrm{C}=0 \%$, Fibre, $\mathrm{F}=0 \%$, Silt, $\mathrm{M}=0 \%$, and mean effective stress of $50 \mathrm{kPa}$

been previously used to model the in situ recycled properties of gypsum and bamboo fibres $[6,40]$.

\section{Testing overview and sample preparation}

In this section monotonic triaxial isotropically consolidated drained (CID) tests are described for compression and extension loading conditions. To understand the drained behavior of unreinforced Toyoura sand and PVA fibre reinforced cemented Toyoura sand, the tests were performed with varying cement $(0-3 \%)$, and fibre $(0-3 \%)$ contents. The unreinforced and reinforced specimens were initially consolidated to target ranges $(50-400 \mathrm{kPa})$ of mean effective stress, $p^{\prime}\left(\frac{\sigma_{1}^{\prime}+2 \sigma_{3}^{\prime}}{3}\right)$. Tables 1 and 2 summarize the testing programs used to evaluate the stress-strain, volumetric strain-axial strain, stress 
Table. 2 Testing program for consolidated drained (CID) extension tests (Current Study)

\begin{tabular}{|c|c|c|c|c|c|c|c|}
\hline Test No. & Test ID & $\begin{array}{l}\text { Mean effective } \\
\text { stress }\left(p^{\prime}\right)(k P a)\end{array}$ & $\begin{array}{l}\text { Cement } \\
\text { content } \\
(\%)\end{array}$ & $\begin{array}{l}\text { Fibre } \\
\text { content } \\
(\%)\end{array}$ & $\begin{array}{l}\text { Silt } \\
\text { content } \\
(\%)\end{array}$ & Lab & Test type C/E \\
\hline \multicolumn{8}{|l|}{ Pure sand } \\
\hline 1. & CD-COFOMO-50 & 50 & 0 & 0 & 0 & WM & $\mathrm{E}$ \\
\hline 2. & CD-COFOMO-100 & 100 & 0 & 0 & 0 & WM & E \\
\hline 3. & CD-COFOMO-200 & 200 & 0 & 0 & 0 & WM & $\mathrm{E}$ \\
\hline 4. & CD-COFOMO-400 & 400 & 0 & 0 & 0 & WM & $\mathrm{E}$ \\
\hline \multicolumn{8}{|l|}{ Fibre only } \\
\hline 5. & CD-COF1M0-50 & 50 & 0 & 1 & 0 & WM & $\mathrm{E}$ \\
\hline 6. & CD-COF1M0-100 & 100 & 0 & 1 & 0 & WM & $\mathrm{E}$ \\
\hline 7. & CD-COF1M0-200 & 200 & 0 & 1 & 0 & WM & $\mathrm{E}$ \\
\hline 8. & CD-COF1M0-400 & 400 & 0 & 1 & 0 & WM & E \\
\hline 9. & CD-COF3M0-50 & 50 & 0 & 3 & 0 & WM & $\mathrm{E}$ \\
\hline 10. & CD-COF3MO-100 & 100 & 0 & 3 & 0 & WM & $\mathrm{E}$ \\
\hline 11. & CD-COF3MO-200 & 200 & 0 & 3 & 0 & WM & $\mathrm{E}$ \\
\hline 12. & CD-COF3MO-400 & 400 & 0 & 3 & 0 & WM & $\mathrm{E}$ \\
\hline \multicolumn{8}{|c|}{ Cement only } \\
\hline 13. & CD-C3FOMO-100 & 100 & 3 & 0 & 0 & FU & $\mathrm{E}$ \\
\hline \multicolumn{8}{|c|}{ Cement and fibre } \\
\hline 14. & CD-C3F1M0-50 & 50 & 3 & 1 & 0 & WM & $\mathrm{E}$ \\
\hline 15. & CD-C3F1M0-100 & 100 & 3 & 1 & 0 & WM & $\mathrm{E}$ \\
\hline 16. & CD-C3F1M0-200 & 200 & 3 & 1 & 0 & WM & $\mathrm{E}$ \\
\hline 17. & CD-C3F1M0-400 & 400 & 3 & 1 & 0 & WM & $\mathrm{E}$ \\
\hline 18. & CD-C3F3M0-50 & 50 & 3 & 3 & 0 & WM & $\mathrm{E}$ \\
\hline 19. & CD-C3F3M0-100 & 100 & 3 & 3 & 0 & WM & $\mathrm{E}$ \\
\hline 20. & CD-C3F3M0-200 & 200 & 3 & 3 & 0 & WM & E \\
\hline 21. & CD-C3F3M0-400 & 400 & 3 & 3 & 0 & WM & E \\
\hline
\end{tabular}

Extension

path behavior, strength envelopes of unreinforced, fibre, cemented, and fibre reinforced cemented Toyoura sand in triaxial compression and extension loading conditions. In the tables, WM denotes a test performed at Western University during the current study. A unique test ID has also been used for each test (e.g., CD-C0F0M0-50), the first part of the ID represents the type of test (drained), the second part shows the percentages of cement $(\mathrm{C})$, Fibre $(\mathrm{F})$, Silt $(\mathrm{M})$, and the last part gives information about the mean effective stress (e.g., 50, 100, 200, and $400 \mathrm{kPa}$ ).

All samples were prepared to a target dry density value (e.g., $\rho_{d}=1.489 \mathrm{~g} / \mathrm{cm}^{3}$ ) of Toyoura sand using under-compaction moist tamping technique [41]. This density has been selected to replicate the field conditions (e.g., medium dense state) of the compacted soil (e.g., Tokyo Bay region) and also to make comparison with the previously published literature $[6,53]$. Unreinforced, fibre, cemented, and fibre reinforced cemented Toyoura sand samples were prepared and mixed to $10 \%$ of water content by dry weight of soil (for unreinforced sand) and total mass of composite material (e.g., fibre, cemented, and fibre reinforced cemented sand). $10 \%$ initial moisture content was utilized to match the previous work of $[6,53]$ from Fukuoka and Western University, who used a similar method 
for monotonic and cyclic triaxial specimen preparation. For the testing programs in this study, the curing duration of the tests has been three days.

A GDS triaxial apparatus was employed to conduct consolidated drained (CD) compression and extension triaxial tests as per accordance to ASTM D7181 [56] to investigate the behavior of unreinforced, fibre only, cement only, and fibre reinforced cemented Toyoura sand specimens. This system is a computer controlled, fully automated advanced GDS Triaxial Testing System (GDSTTS). The GDS Standard Level Pressure/ Volume Controllers (STDDPC) allow for pressure measurements to be resolved to $1 \mathrm{kPa}$, with an accuracy of $\pm 1.5 \mathrm{kPa}$ up to a maximum pressure of $2 \mathrm{MPa}$. Volume changes can be resolved to $1 \mathrm{~mm}^{3}$ at an accuracy of $<0.25 \%$ of the current measurement. A $15 \mathrm{kN}$ load balanced internal load cell was installed providing an accuracy of $\pm 1 \mathrm{~N}$ [56].

All of the specimens were saturated with de-aired water and $\mathrm{CO}_{2}$ until a B-value of at least 0.96 was reached, before starting the consolidation stage. First, carbon dioxide $\left(\mathrm{CO}_{2}\right)$ was slowly flushed through the bottom of the sample for about $30 \mathrm{~min}$ to absorb any entrapped air in the voids of specimen with a gradient of pressure for approximately $3 \mathrm{kPa}$. The top and bottom drainage lines were flushed with de-aired water through back pressure pump at a very slow rate. After flushing the drainage lines, then de-aired water was flushed in the specimen at a very slow rate to fill the voids of specimen and replace $\mathrm{CO}_{2}$. In addition, the pore water pressure values were also monitored during $\mathrm{CO}_{2}$ percolation and flushing with water. It was necessary to maintain an effective stress of approximately $3 \mathrm{kPa}$ in order to minimize any sample disturbance. Once the $\mathrm{CO}_{2}$ percolation and flushing with water was finished, the cell pressure was ramped to $320 \mathrm{kPa}$ and back pressure was ramped to $310 \mathrm{kPa}$, maintaining an effective stress of $10 \mathrm{kPa}$. In the next stage, cell pressure was then ramped to $330 \mathrm{kPa}$ (e.g. the back pressure $310 \mathrm{kPa}$ was kept constant and cell pressure starting at $320 \mathrm{kPa}$ was then increased at a rate of $2-3 \mathrm{kPa} /$ minute, till the final target cell pressure of $330 \mathrm{kPa}$ was reached) and pore pressure coefficient $\mathrm{B}$ was checked during the saturation stage. Higher B-values were possible in the cemented samples due to the application of higher back pressures (e.g., $320 \mathrm{kPa}$ ), short curing duration (e.g., 3 days), and lower cement contents ( $0-3 \%)$. All of specimens for the consolidated drained $(\mathrm{CD})$ tests were isotropically consolidated to the desired mean effective stress (e.g., 150, 100, 200, $400 \mathrm{kPa}$ ) under computer control. The consolidation stage was continued until $100 \%$ primary consolidation was reached. The rate of axial displacement used to shear all of the specimens was $0.06 \mathrm{~mm} / \mathrm{min}[50,53,58]$ to eliminate any concerns over rate effects, when comparing the results.

\section{Results and discussion}

\section{Deviator stress vs. axial strain response}

Figure 3a-e shows the deviator stress and axial strain responses observed in the drained (CID) compression and extension tests. The trend of the drained compression results shows typical behavior of medium dense specimens with an absence of a significant stress peak. The unreinforced specimens exhibited a behavior of medium dense sand and reached a peak deviator stress $\left(q_{p}\right)$ at approximately $4 \%$ axial strain $\left(\epsilon_{a}\right)$ for the varying mean effective stresses, $p^{\prime}$ (i.e. $50-400 \mathrm{kPa}$ ). However, for the fibre reinforced specimens the peak deviator stresses were observed at approximately $6 \%$ axial strain. For the fibre 


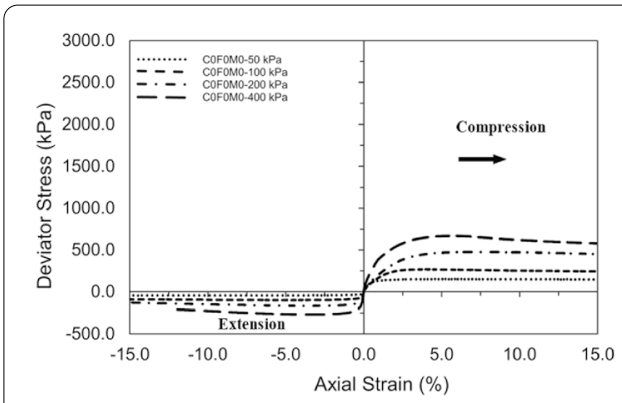

(a) Pure Sand

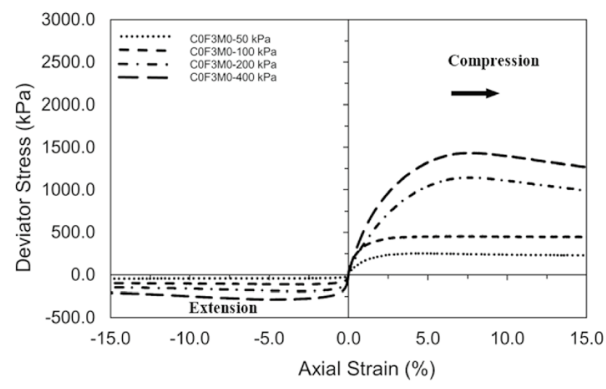

(c) $3 \%$ Fibre

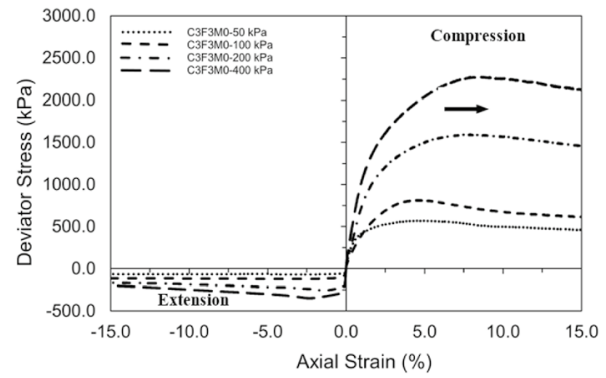

(e) $3 \%$ Cement $+3 \%$ Fibre

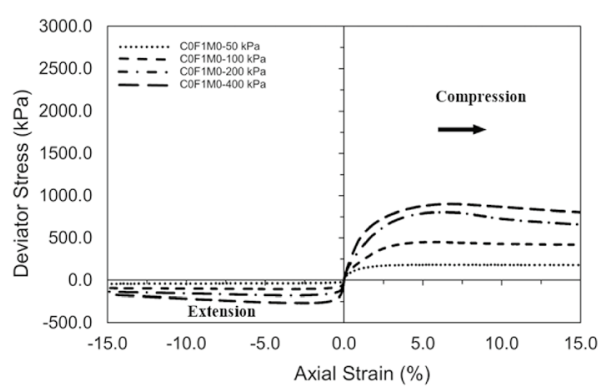

(b) $1 \%$ Fibre

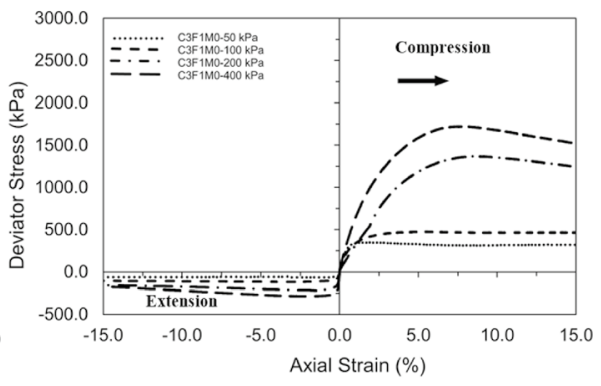

(d) $3 \%$ Cement $+1 \%$ Fibre

Fig. 3 Deviatoric stress $(q)$ versus axial strain $\left(\epsilon_{a}\right)$ curves from CID compression and extension tests for unreinforced, fibre, and fibre reinforced cemented Toyoura sand specimens consolidated to varying mean effective stresses ( $p$ ) a Pure sand $\mathbf{b} 1 \%$ fibre c $3 \%$ fibre $\mathbf{d} 3 \%$ cement $+1 \%$ fibre e $3 \%$ cement $+3 \%$ fibre

reinforced cemented specimens, the peak stresses were observed at approximately $8 \%$ strain. In addition, fibre reinforced cemented specimens show relatively stiffer response compared to the pure Toyoura sand specimens. Fibres are observed to be the least effective for smaller strain ranges $(0-1 \%)$ due to the lack of fibre-soil matrix interaction and are found to have minimum effect on the initial stiffness of specimens. In general, the unreinforced and fibre reinforced cemented sand samples show lower peak response when consolidated under lower effective stresses $(50 \mathrm{kPa}$ and $100 \mathrm{kPa})$. However, specimen subjected to higher effective stresses $(200 \mathrm{kPa}$ and $400 \mathrm{kPa})$ exhibited a more noticeable peak. Overall, fibres have been observed to be more effective when specimens are subjected to higher effective stresses $(200 \mathrm{kPa}$ and $400 \mathrm{kPa})$. These findings might be due to a better contact between sand-fibre interaction or sand-cement-fibre bonding and interaction under higher effective stresses. Again, the reasons for the absence of significant peak for the fibre reinforced cemented specimen results might be attributed to 
relatively short duration of curing (e.g. 3 days) and use of low cement contents (0-3\%). However, it has been shown that the peak and deviator stresses at critical state have been noticeably increased by the inclusion of fibres and cement additives. No strain hardening could be seen in the fibre and fibre reinforced cemented sand as reported by other researchers [57], which is contrary to the results presented by Diambra [3] for fibre reinforced sand. The peak drained strength increases in fibre reinforced cemented specimens were found to be up to $132 \%$ (lower effective stresses) and $243 \%$ (higher effective stresses), while, the drained strength increases at critical state for the fibre reinforced cemented specimens were found to be up to $105 \%$ (lower effective stresses) and 245\% (higher effective stresses). Similar results and investigations have also been reported for fibre reinforced Hostun sand, [3] and fibre reinforced cemented Portaway sand [5759]. The significant strength increases at higher effective stress can be attributed to the enhanced frictional interaction between particles and fibres (e.g., interlocking due to micro-striations) and the mobilized tensile resistance due to modulus of fibres.

In the extension tests, fibres alone were the least effective and the net peak drained strength increase in fibre reinforced cemented specimens were found to be approximately $50 \%$ (in case of lower effective stresses) and $44 \%$ (in case of higher effective stresses), while, the drained strength increases at critical state in the fibre reinforced cemented specimens have been found to be up to approximately $47 \%$ (lower effective stresses) and 35\% (higher effective stresses). In the compression tests, the peak drained strength increases in fibre reinforced cemented specimens were found to be $132 \%$ (lower effective stresses) and $243 \%$ (higher effective stresses), while, the drained strength increases at critical state in fibre reinforced cemented specimens were found to be $105 \%$ (lower effective stresses) and $245 \%$ (higher effective stresses). Overall, the fibre and cement additives increased the stiffness, peak and strength at critical state of pure Toyoura sand but were found to be least effective in extension loading. Diambra et al. [34] demonstrated that the preferred horizontal bedding of fibres or fibre orientation induced by the moist tamping technique can be considered responsible for this limited increase in extension loading conditions.

Figure $4 \mathrm{a}-\mathrm{d}$ shows the stress ratio $\left(q / p^{\prime}\right)$ versus axial strain $\left(\epsilon_{a}\right)$ curves from the drained (CID) compression tests for unreinforced, fibre, and fibre reinforced cemented Toyoura sand specimens consolidated to different mean effective stress $\left(p^{\prime}\right)$. It can be seen that the stress ratio, peak and critical state stress ratios increases with the addition of fibres and cement. Similar results and investigations have also been reported for fibre reinforced Hostun sand [3] and fibre reinforced cemented Portaway sand [57-59].

Figure 5 show the effect of fibre and cement additives on the secant modulus $\left(\mathrm{E}_{50}\right)$ of pure Toyoura sand. Overall, the secant modulus is changed very little (i.e., 3-5\%) for the fibre reinforced specimens. However, a significant improvement in the secant modulus is observed for the fibre reinforced cemented specimens. For example, Toyoura sand reinforced with $3 \%$ cement and 1-3\% fibre, has an increase in secant modulus of approximately $67 \%$.

\section{Volumetric strain response}

Volumetric strain versus axial strain behavior observed in the drainedtriaxial compression and extensiontests are shown in Fig. 6a-e. The unreinforced and reinforced 


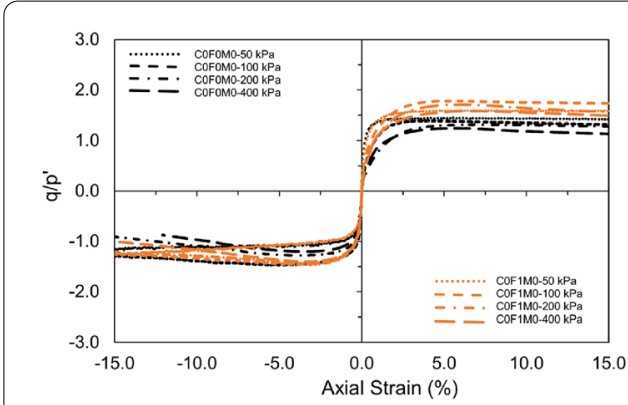

(a) Pure Sand and $1 \%$ Fibre

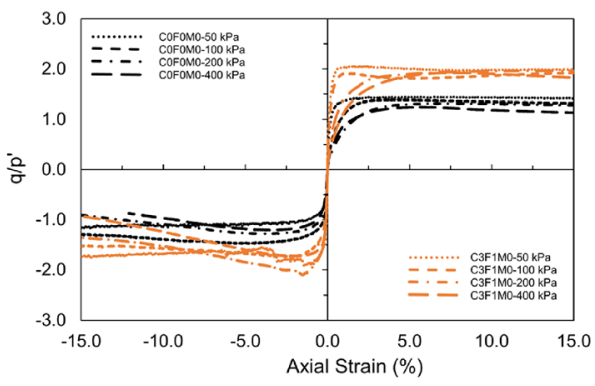

(c) Pure Sand and 3\% Cement $+1 \%$ Fibre

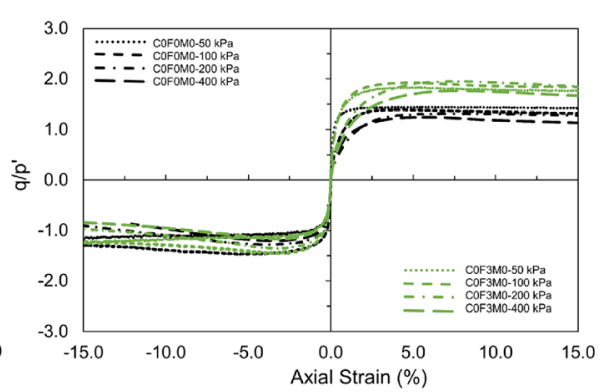

(b) Pure Sand and 3\% Fibre

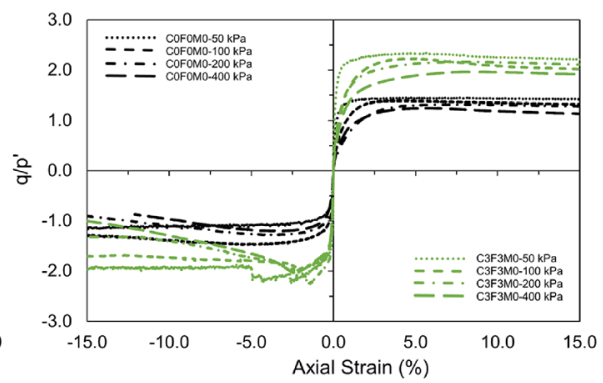

(d) Pure Sand and 3\% Cement $+3 \%$ Fibre

Fig. 4 Stress ratio $\left(q / p^{\prime}\right)$ versus axial strain $\left(\epsilon_{a}\right)$ curves from CID tests for unreinforced, fibre, and fibre reinforced cemented Toyoura sand specimens consolidated to varying mean effective stresses $(p)$ a Pure sand and $1 \%$ fibre b Pure sand and 3\% fibre c Pure sand and 3\% cement $+1 \%$ fibre d Pure sand and 3\% cement $+3 \%$ fibre

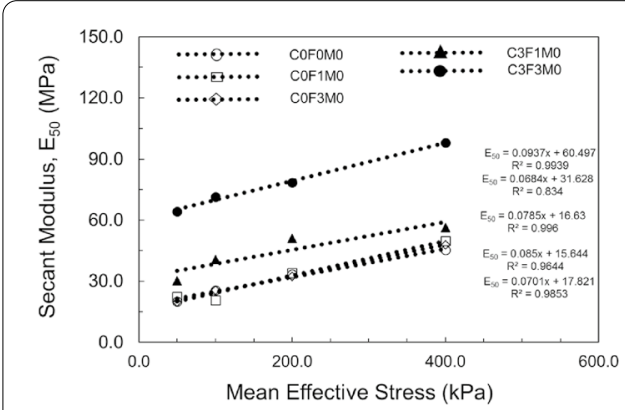

(a)

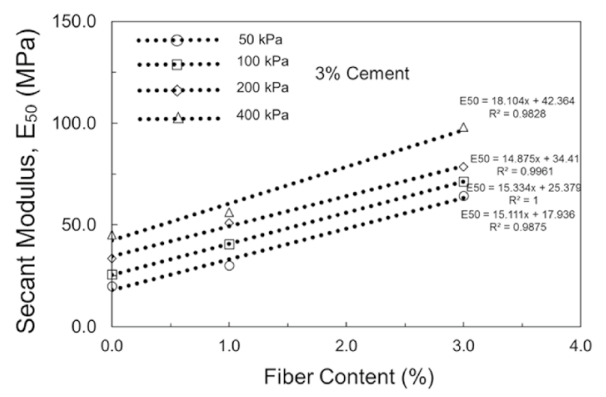

(c)

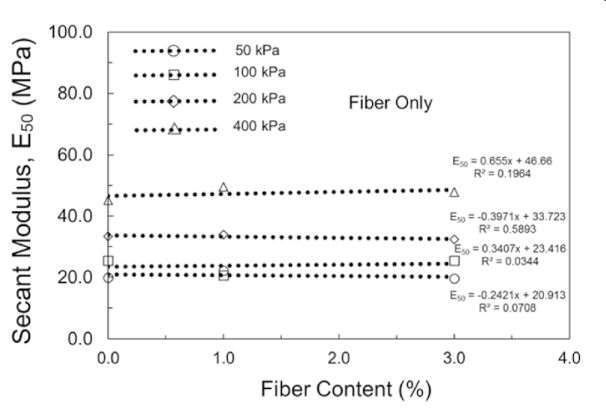

(b)

Fig. 5 Secant modulus $\left(E_{50}\right)$ from CID tests for unreinforced, fibre, and fibre reinforced cemented Toyoura sand specimens consolidated to varying mean effective stresses ( $p$ ) a Secant modulus versus mean effective stress $\mathbf{b}$ Secant modulus with fibre content only c Secant modulus versus $3 \%$ cement + fibre 


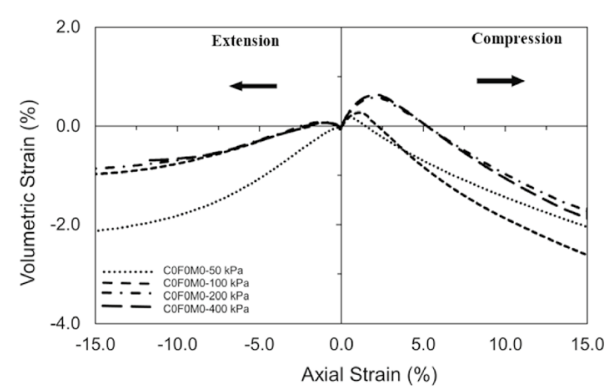

(a) Pure Sand

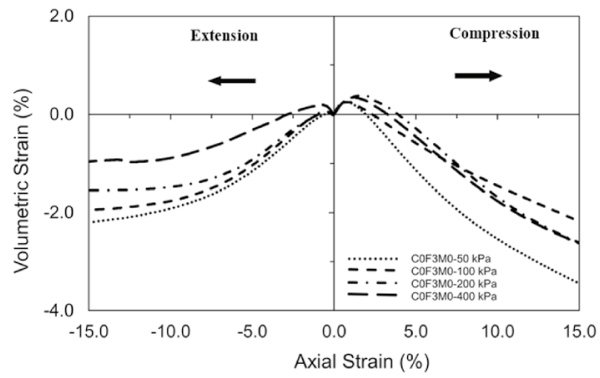

(c) $3 \%$ Fibre

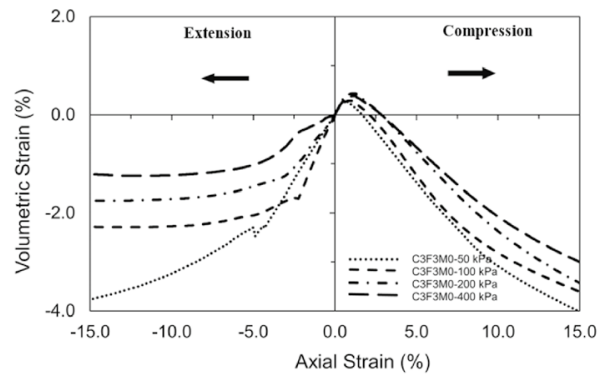

(e) $3 \%$ Cement $+3 \%$ Fibre

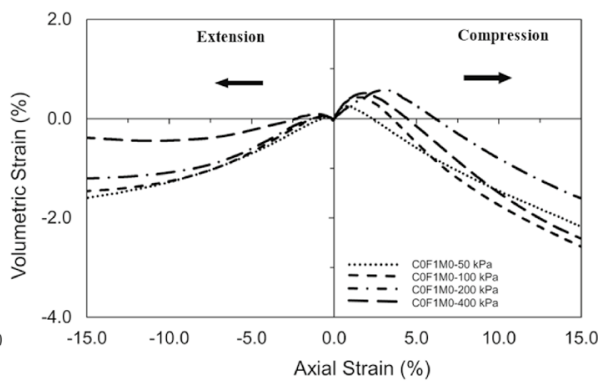

(b) $1 \%$ Fibre

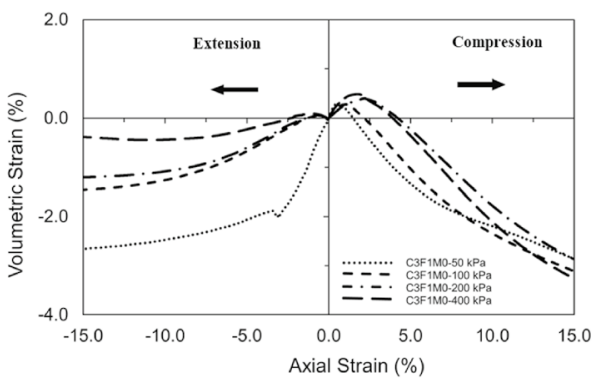

(d) $3 \%$ Cement $+1 \%$ Fibre

. 6 volumetric strain $\left(\boldsymbol{\epsilon}_{\mathrm{v}}\right)$ vs axialstrain $\left(\boldsymbol{\epsilon}_{\mathrm{a}}\right)$ curves from CID compression and extension tests for unreinforced, fibre, and fibre reinforced cemented Toyoura sand specimens consolidated to varying mean effective stresses ( $p$ ) a Pure sand $\mathbf{b} 1 \%$ fibre c 3\% fibre $\mathbf{d} 3 \%$ cement $+1 \%$ fibre e $3 \%$ cement $+3 \%$ fibre

specimens revealed classical response for compacted soils in compression at small strains $(0-2 \%)$, followed by significant dilation as they reached medium to high strains (5-15\%). In addition, the amount of dilation was observed to decrease with higher mean effective stresses. The volumetric strain versus axial strain results show reasonably constant volume shearing behavior for pure Toyoura sand, and fibre reinforced sand, but fibre reinforced cemented sand specimens show slight variations in volumetric behavior at high strain.

For drained (CID) triaxial compression loading conditions, when subjected to lower effective stresses (e.g. $50 \mathrm{kPa}$ and $100 \mathrm{kPa}$ ) the specimens developed positive volumetric strain (compression) reaching 0.4 to $0.8 \%$. In contrast, when subjected to higher effective stresses (e.g. $200 \mathrm{kPa}$ and $400 \mathrm{kPa}$ ) the samples developed higher positive volumetric strain (compression) reaching 1.0 to $1.5 \%$. The difference at high axial strain of the volumetric strains for unreinforced and reinforced specimens was found to be approximately $3.5 \%$, when subjected to effective stress of $50 \mathrm{kPa}$. However, for the rest of effective 
Table. 3 Peak dilatancy angles from the CID compression tests for unreinforced, fibre reinforced, and fibre reinforced cemented Toyoura sand specimens

\begin{tabular}{llllll}
\hline $\begin{array}{l}\mathbf{p}^{\prime} \\
(\mathbf{k P a})\end{array}$ & $\begin{array}{l}\text { COF0M0 } \\
\boldsymbol{\Psi}_{\mathbf{p}}\left({ }^{\circ}\right)\end{array}$ & $\begin{array}{l}\text { COF1M0 } \\
\boldsymbol{\Psi}_{\mathbf{p}}\left({ }^{\circ}\right)\end{array}$ & $\begin{array}{l}\text { COF3M0 } \\
\boldsymbol{\Psi}_{\mathbf{p}}\left({ }^{\circ}\right)\end{array}$ & $\begin{array}{l}\text { C3F1M0 } \\
\boldsymbol{\Psi}_{\mathbf{p}}\left({ }^{\circ}\right)\end{array}$ & $\begin{array}{l}\text { C3F3M0 } \\
\boldsymbol{\Psi}_{\mathbf{p}}\left({ }^{\circ}\right)\end{array}$ \\
\hline 50 & 8.3 & 8.2 & 14.5 & 14.9 & 17.5 \\
100 & 10.7 & 9.9 & 8.3 & 13.5 & 16.3 \\
200 & 6.6 & 7.1 & 10.1 & 11.7 & 13.4 \\
400 & 6.4 & 8.6 & 12.5 & 10.2 & 11.8 \\
\hline
\end{tabular}

stresses (e.g. $100 \mathrm{kPa}, 200 \mathrm{kPa}$, and $400 \mathrm{kPa}$ ), the difference in volumetric strain have been examined to be approximately 0.8 to $1.5 \%$. Hence, for both unreinforced and reinforced specimens there is a decrease in volumetric strain with greater effective stresses or in other words, the rate of dilation decreases with increases in effective stresses, as seen in Table 3. In addition, it was shown that the development of volumetric strain plays an important role in the mobilization resistance of fibre-sand or fibre-sand-cement matrix. Similar results and findings were reported for fibre reinforced Hostun sand, [3, 37, 39] and fibre reinforced cemented Portaway sand [57-59].

For the drained extension loading conditions, when subjected to lower mean effective stresses $(50 \mathrm{kPa}$ and $100 \mathrm{kPa})$ developed significantly lower positive volumetric strain (compression) reaching $0-0.2 \%$. In contrast, specimens, when subjected to higher mean effective stresses $(200 \mathrm{kPa}$ and $400 \mathrm{kPa})$ developed slightly higher positive volumetric strain (compression) reaching the range of $0-0.4 \%$. The difference at high axial strain of the volumetric strain for unreinforced and reinforced specimens was found to be approximately $3.9 \%$, when subjected to mean effective stress of $50 \mathrm{kPa}$.

However, for the other effective stresses $(100,200$, and $400 \mathrm{kPa})$, the difference in volumetric strain was found to be approximately $0.5-1.0 \%$. Hence, the results for the CID extension tests indicate that, for both unreinforced and reinforced specimens, there is a decrease in volumetric strain with increasing mean effective stresses. Thus, the rate of dilation decreases with increasing effective stresses. Similar results were found for the triaxial compression tests. However, contrary to the compression tests, significantly lower positive volumetric strain (compression) was investigated in extension loading (in the range of $0.2-0.5 \%$ ).

The mobilized angle of dilatancy for triaxial conditions is defined as the inverse tangent of the ratio of incremental volumetric and axial strains [3]. For simplicity it is often assumed that the elastic components of the strain increments are small compared with the plastic components (denoted with the superscript ${ }^{p}$ ), thus:

$$
\tan \psi=-\frac{\dot{\epsilon}_{v}^{p}}{\left|\dot{\epsilon}_{a}^{p}\right|} \approx-\frac{\dot{\epsilon}_{v}}{\left|\dot{\epsilon}_{a}\right|}
$$

Where $\psi=$ dilatancy angle, $\dot{\epsilon}_{v}=$ incremental volumetric strain, and $\dot{\epsilon}_{a}=$ incremental axial strain.

Figure 7 shows the state parameter $\left(\psi_{p m}\right)$ against axial strain $\left(\epsilon_{\mathrm{a}}\right)$ curves from the CD compression and extension tests for unreinforced, fibre, and fibre reinforced cemented Toyoura sand specimens consolidated to different mean effective stresses $\left(p^{\prime}\right)$. It can be 


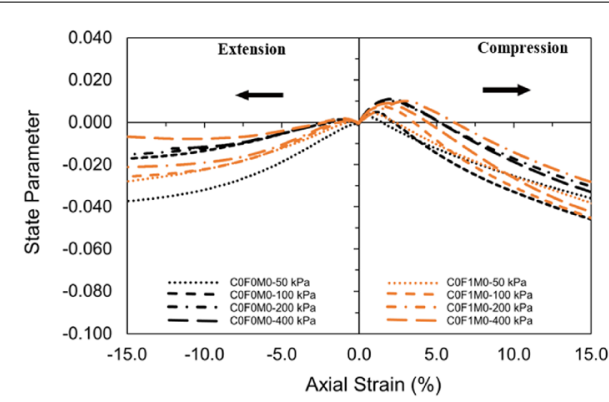

(a) Pure Sand and $1 \%$ Fibre

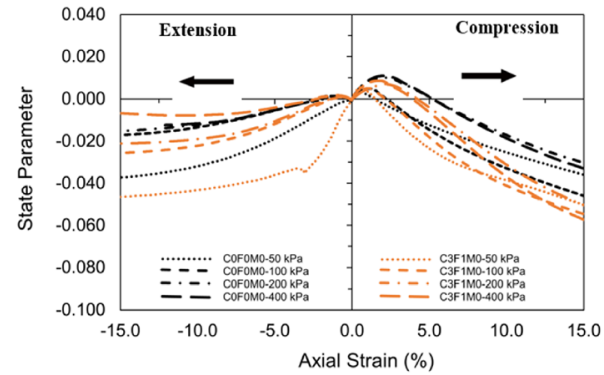

(c) Pure Sand and 3\% Cement $+1 \%$ Fibre

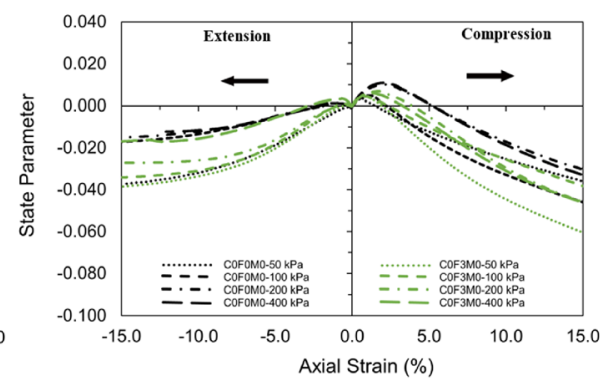

(b) Pure Sand and 3\% Fibre

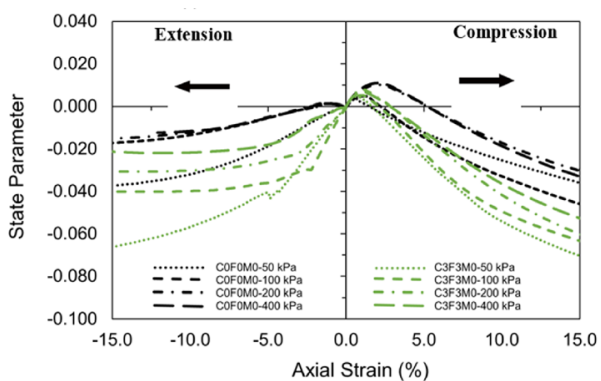

(d) Pure Sand and 3\% Cement $+3 \%$ Fibre

Fig. 7 State parameter $\left(\psi_{p m}\right)$ vs axial strain $\left(\epsilon_{a}\right)$ curves from CIDcompression and extension tests for unreinforced, fibre, and fibre reinforced cemented Toyoura sand specimens consolidated to varying mean effective stresses ( $p$ ) a Pure sand and 1\% fibre b Pure sand and 3\% fibre c Pure sand and 3\% cement + 1\% fibre $\mathbf{d}$ Pure sand and $3 \%$ cement $+3 \%$ fibre

seen that the state parameter increases with the addition of fibres and cement. Also, it is seen that the state parameter decreases with higher mean effective stress for unreinforced and reinforced specimens.

Figura 8 shows the peak dilatancy angle against the state parameterobtained from CID tests for unreinforced, fibre, and fibre reinforced cementedToyoura sand specimens. It can be seen that pure Toyoura sand has a peakdilatancy angle of approximately $5-8^{\circ}$, fibre reinforced specimens have a peakdilatancy angle of approximately $6-14^{\circ}$, and fibre reinforced cemented specimenshave a peak dilatancy angle of approximately $9-17^{\circ}$. The state parameter forpure sand is approximately -0.032 to $-0.045,-0.032$ to -0.065 for fibrereinforced sand, and -0.05 to 0.075 for fibre reinforced cemented specimens. Overall, the state parameter decreases with the inclusion of fibre and cementadditives.

\section{Strength envelopes and strength parameters}

Figure 9 shows the strength envelopes obtained from the drained compression and extension tests in deviator stress versus the mean effective stress space for specimens consolidated to different mean effective stresses (e.g. 50-400 kPa). This shows that the deviator strength increases with greater cement and fibre content. The slope of the critical state line significantly increases with increasing percentages of cement and fibres. The magnitudes of the slopes of the critical state lines are also summarized in Table 5; Fig. 11. The peak frictional angle vs. state parameter from CID compression 


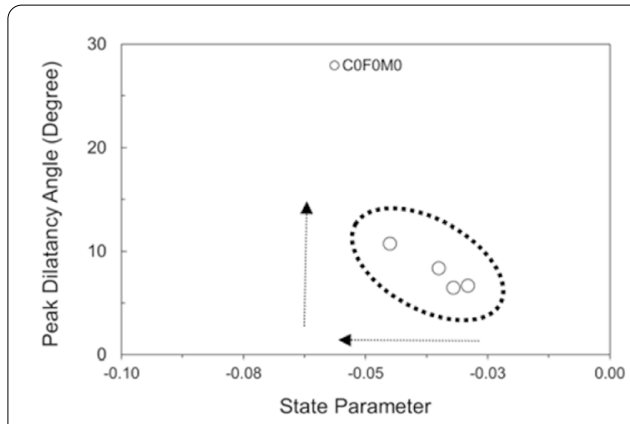

(b) Pure Sand

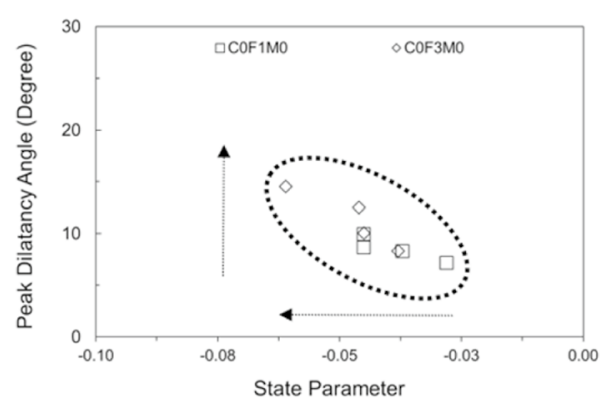

(a) Pure sand with $1 \%$ and $3 \%$ Fibre

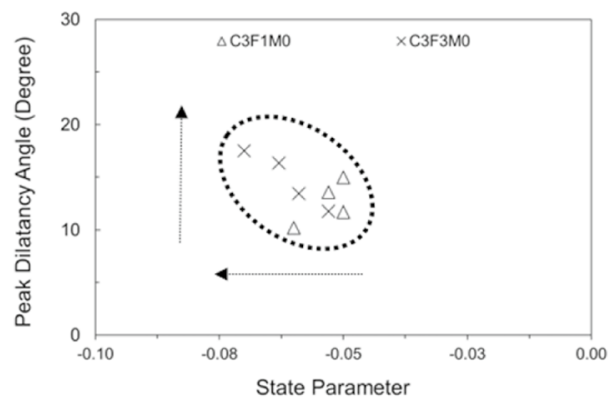

(c) Pure sand, $3 \%$ cement with $1 \%$ and $3 \%$ fibre

Fig. 8 Peak dilatancy angle vs. state parameter from CID tests for unreinforced, fibre, and fibre reinforced cemented Toyoura sand specimens a Pure sand with $1 \%$ and $3 \%$ fibre b Pure sand $\mathbf{c}$ Pure sand, $3 \%$ cement with $1 \%$ and $3 \%$ fibre

Table. 4 Mohr-Coulomb strength parameters, $\boldsymbol{c}_{\boldsymbol{p}}^{\prime}$ and $\boldsymbol{\varphi}_{\boldsymbol{p}}^{\prime}$, for unreinforced, fibre reinforced, and fibre reinforced cemented Toyoura sand from CID compression tests

\begin{tabular}{|c|c|c|c|c|c|c|c|c|c|}
\hline \multicolumn{10}{|l|}{ At peak } \\
\hline COFOMO & & COF1MO & & COF3MO & & C3F1M0 & & C3F3M0 & \\
\hline $\mathbf{c}^{\prime}(\mathrm{kPa})$ & $\varphi^{\prime}\left({ }^{\circ}\right)$ & $\mathrm{C}^{\prime}(\mathrm{kPa})$ & $\varphi^{\prime}\left({ }^{\circ}\right)$ & $\mathrm{c}^{\prime}(\mathrm{kPa})$ & $\varphi^{\prime}\left({ }^{\circ}\right)$ & $\mathrm{C}^{\prime}(\mathrm{kPa})$ & $\varphi^{\prime}\left({ }^{\circ}\right)$ & $c^{\prime}(\mathrm{kPa})$ & $\varphi^{\prime}\left(^{\circ}\right)$ \\
\hline 0 & $34.5^{\circ}$ & 38 & $40.5^{\circ}$ & 93 & $45^{\circ}$ & 109 & $47.5^{\circ}$ & 134 & $52^{\circ}$ \\
\hline
\end{tabular}

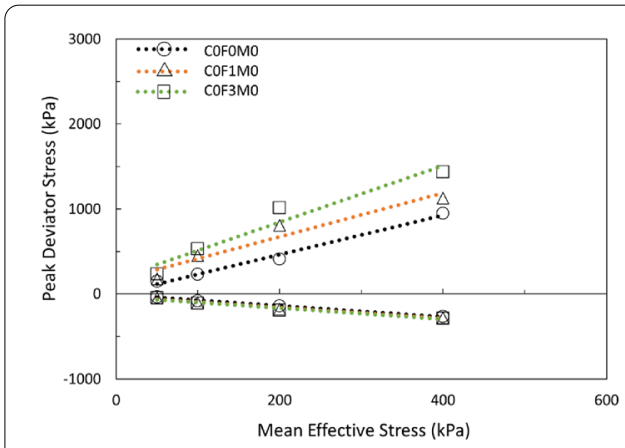

(b) Pure Sand, 1\% Fibre, 3\% Fibre

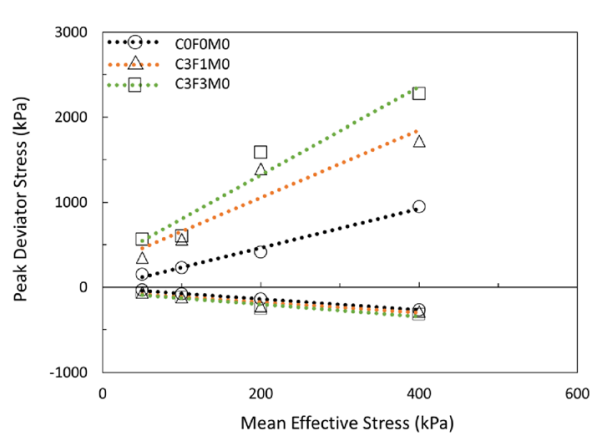

(a) Pure Sand, 3\% Cement $+1 \%$ Fibre, $3 \%$ Cement $+3 \%$ Fibre

Fig. 9 Strength envelopes from CID compression and extension tests for unreinforced, fibre, and fibre reinforced cemented Toyoura sand specimens consolidated to varying mean effective stresses a Pure sand, $3 \%$ cement $+1 \%$ fibre, $3 \%$ cement $+3 \%$ fibre b Pure sand, $1 \%$ fibre, $3 \%$ fibre 
Table. 5 Slope of the critical state line, $M$ for unreinforced, fibre reinforced, and fibre reinforced cemented Toyoura sand from CID compression tests

\begin{tabular}{|c|c|c|c|c|c|c|c|c|c|}
\hline \multicolumn{10}{|c|}{ At critical state } \\
\hline \multicolumn{2}{|c|}{ COFOMO } & \multicolumn{2}{|c|}{ COF1MO } & \multicolumn{2}{|c|}{ COF3MO } & \multicolumn{2}{|c|}{ C3F1M0 } & \multicolumn{2}{|c|}{ C3F3M0 } \\
\hline$\varphi_{c s}^{\prime}\left({ }^{\circ}\right)$ & M & $\left.\varphi^{\prime}{ }_{c s}{ }^{\circ}\right)$ & M & $\left.\varphi^{\prime}{ }_{C S}{ }^{(}\right)$ & M & $\left.\varphi_{C S}^{\prime}{ }^{(}\right)$ & M & $\varphi_{c s}^{\prime}\left({ }^{\circ}\right)$ & M \\
\hline $27.5^{\circ}$ & 1.09 & $34^{\circ}$ & 1.37 & $36.5^{\circ}$ & 1.48 & $39^{\circ}$ & 1.59 & $43.5^{\circ}$ & 1.78 \\
\hline
\end{tabular}

Table. 6 Mohr-Coulomb strength parameters, $\boldsymbol{c}_{\boldsymbol{p}}$ and $\boldsymbol{\varphi}_{\boldsymbol{p}}^{\prime}$, for unreinforced, fibre reinforced, and fibre reinforced cemented Toyoura sand from CID extension tests

\begin{tabular}{|c|c|c|c|c|c|c|c|c|c|}
\hline \multicolumn{10}{|l|}{ At peak } \\
\hline \multicolumn{2}{|l|}{ COFOMO } & \multicolumn{2}{|c|}{ COF1MO } & \multicolumn{2}{|c|}{ COF3MO } & \multicolumn{2}{|c|}{ C3F1M0 } & \multicolumn{2}{|c|}{ C3F3M0 } \\
\hline $\mathbf{c}^{\prime}(\mathrm{kPa})$ & $\varphi^{\prime}\left({ }^{\circ}\right)$ & $\mathrm{c}^{\prime}(\mathrm{kPa})$ & $\varphi^{\prime}\left({ }^{\circ}\right)$ & $\mathrm{C}^{\prime}(\mathrm{kPa})$ & $\varphi^{\prime}\left({ }^{\circ}\right)$ & $c^{\prime}(\mathrm{kPa})$ & $\varphi^{\prime}\left({ }^{\circ}\right)$ & $c^{\prime}(\mathrm{kPa})$ & $\varphi^{\prime}\left({ }^{\circ}\right)$ \\
\hline 0 & $29.5^{\circ}$ & 10 & $31.5^{\circ}$ & 19 & $34.8^{\circ}$ & 23 & $35.4^{\circ}$ & 46 & $39.8^{\circ}$ \\
\hline
\end{tabular}

and extension tests for unreinforced, fibre, and fibre reinforced cemented Toyoura sand specimens is presented in Fig. 12.

Table 4 summarizes, and Fig. 10 shows the magnitudes of the peak strength parameters obtained from the drained compression tests performed on the unreinforced, fibre reinforced, and fibre reinforced cemented Toyoura sand specimens. The peak strength parameters significantly increase with the addition of fibre and cement. For example, for $3 \%$ fibre and $3 \%$ cement (C3F3M0), the peak cohesion intercept increases by $134 \%$. In addition, the peak frictional angle increases by almost $51 \%$, and the frictional angle at high strain increases by $67 \%$. Moreover, even for $1 \%$ fibre reinforcement (COF1M0), the increase in peak cohesion intercept is $38 \%$. Furthermore, peak frictional angle increases by $17 \%$, and frictional angle at high strain increases by $24 \%$. Hence, it is shown that the contribution of fibre and cement additives to the strength of pure Toyoura sand are significant from the tests performed. Similar results and findings have also been reported for fibre reinforced Hostun RF (S28) sand [3] and fibre reinforced cemented Portaway sand [39, 57-59]. Table 5 summarizes the results of critical state friction angle $\left(\varphi^{\prime}{ }_{c s}\right)$ and slope of the critical state line $(M)$ obtained from CID compression tests.

Table 6 summarizes the magnitudes of the peak strength parameters $\left(c_{p}^{\prime}\right.$ and $\left.\varphi_{p}^{\prime}\right)$ obtained from the drained extension tests on specimens. The peak strength parameters slightly increase with the addition of fibre and cement. For example, for the $3 \%$ fibre and $3 \%$ cement (C3F3M0), the peak cohesion intercept increases by $46 \%$. In addition, the peak frictional angle increases by almost $35 \%$, and frictional angle at high axial strain increases by $59 \%$. Moreover, even for $1 \%$ fibre reinforcement (COF1M0), the increase in peak cohesion intercept is approximately $10 \%$. Furthermore, peak frictional angle increases by $7 \%$, and frictional angle at high strain increases by $11 \%$. Hence, it is shown that the contribution of fibre and cement additives to the strength of pure Toyoura sand in extension tests are not as noticeable compared to the tests performed with compression loading conditions. Similar results and findings were also reported for 
Table. 7 Slope of the critical state line, Mfor unreinforced, fibre reinforced, and fibre reinforced cemented Toyoura sand from CID extension tests

\begin{tabular}{|c|c|c|c|c|c|c|c|c|c|}
\hline \multicolumn{10}{|c|}{ At critical state } \\
\hline \multicolumn{2}{|c|}{ COFOMO } & \multicolumn{2}{|c|}{ COF1M0 } & \multicolumn{2}{|c|}{ COF3MO } & \multicolumn{2}{|c|}{ C3F1M0 } & \multicolumn{2}{|c|}{ C3F3M0 } \\
\hline$\varphi_{\text {cs }}^{\prime}\left(^{\circ}\right)$ & M & $\varphi_{C S}^{\prime}\left(^{\circ}\right)$ & M & $\varphi_{C S}^{\prime}\left({ }^{\circ}\right)$ & M & $\varphi_{C S}^{\prime}\left({ }^{\circ}\right)$ & M & $\varphi_{C S}^{\prime}\left({ }^{\circ}\right)$ & M \\
\hline $19.8^{\circ}$ & 0.61 & $22^{\circ}$ & 0.66 & $25.2^{\circ}$ & 0.75 & $23.8^{\circ}$ & 0.71 & $26.5^{\circ}$ & 0.77 \\
\hline
\end{tabular}

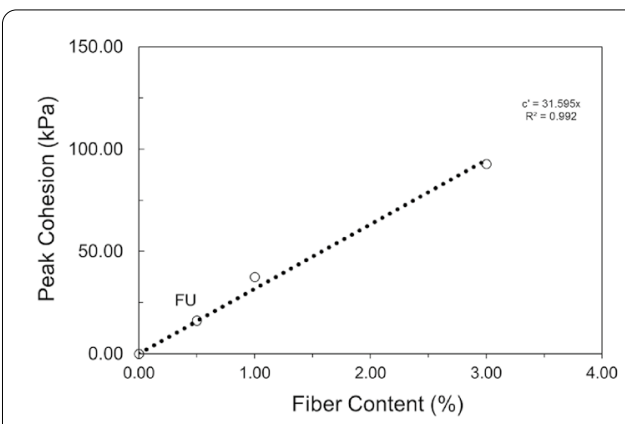

(a)

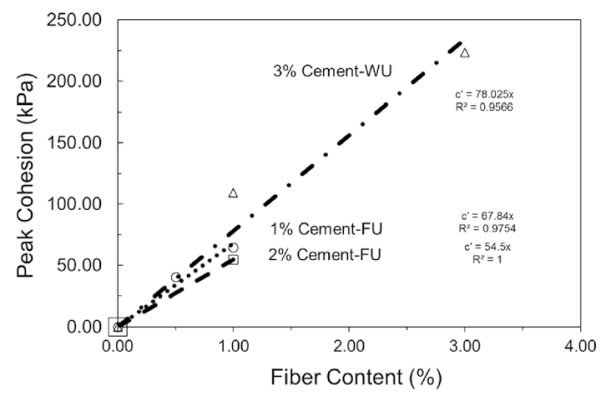

(c)

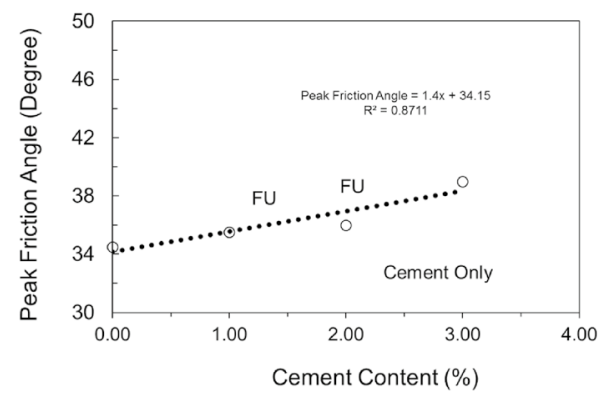

(e)

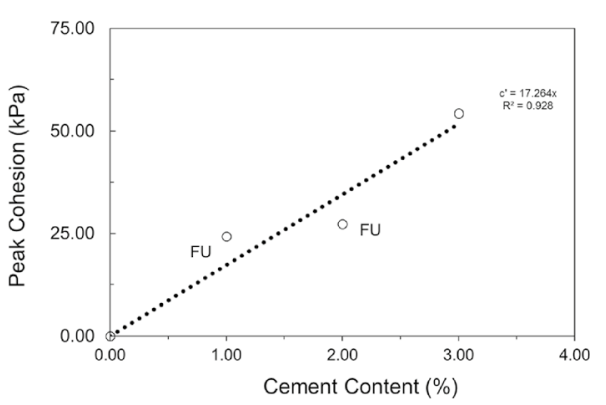

(b)

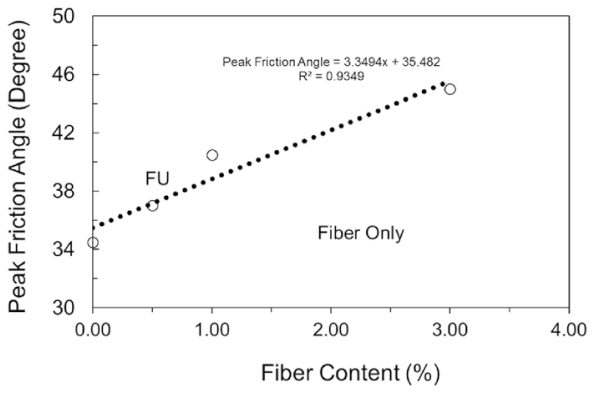

(d)

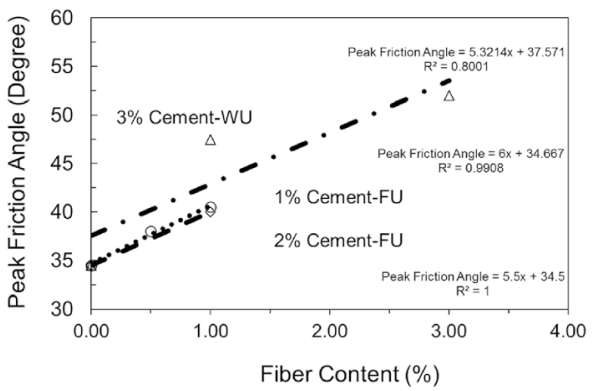

(f)

Fig. 10 Strength parameters for unreinforced, fibre, and fibre reinforced cemented Toyoura sand from CID tests a Peak cohesion versus fibre content $\mathbf{b}$ Peak cohesion versus cement content $\mathbf{c}$ Peak cohesion versus fibre with varying cement contents $\mathbf{d}$ Peak friction angle versus fibre content $\mathbf{e}$ Peak friction angle versus cement content $\mathbf{f}$ Peak friction angle versus fibre with varying cement content

fibre reinforced Hostun sand $[3,37,39]$. Table 5 summarizes the results of critical state friction angle $\left(\varphi_{c s}^{\prime}\right)$ and slope of the critical state line $(M)$ obtained from CID extension tests.

The difference between the critical state friction angles for pure sand and reinforced sand obtained from CIU and CID compression tests range from 18 to $20 \%$. For extension 

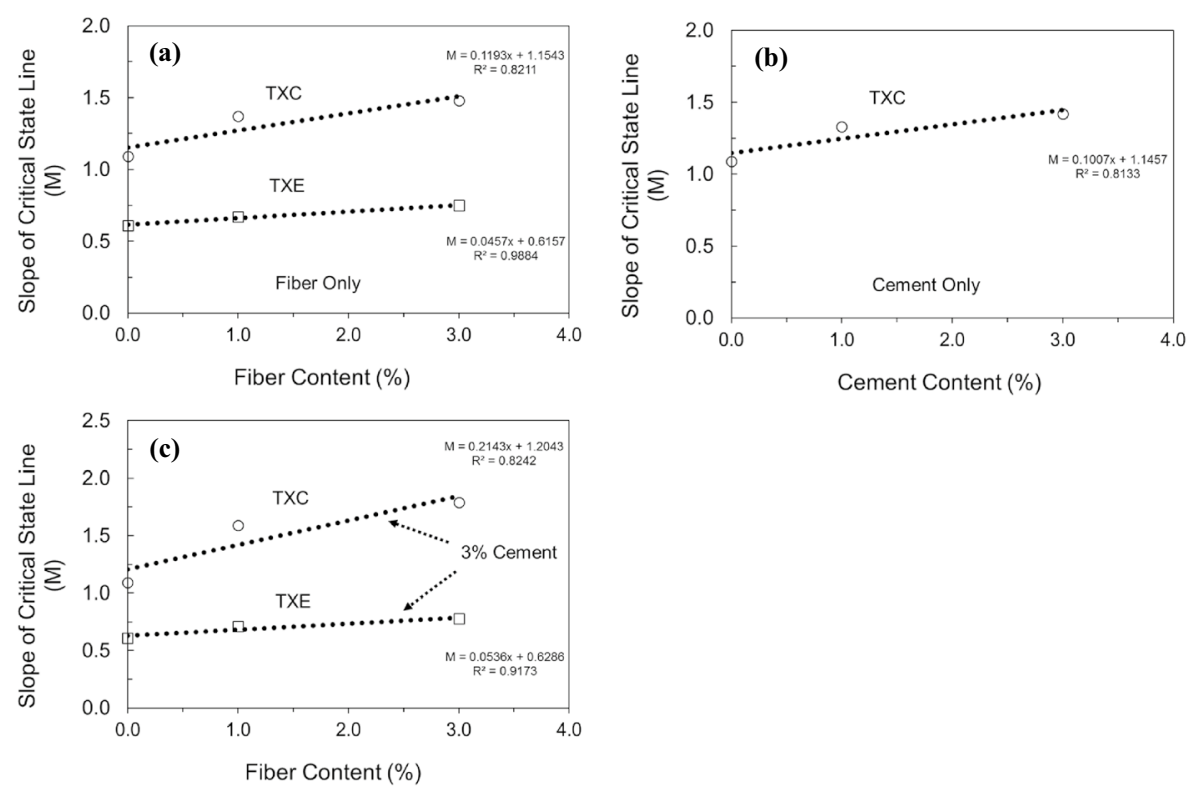

Fig. 11 Slope of the critical state line from CID tests for unreinforced, fibre, and fibre reinforced cemented Toyoura sand specimens $\mathbf{a}$ Slope of critical state line versus fibre content $\mathbf{b}$ Slope of critical state line versus cement content $\mathbf{c}$ Slope of critical state line versus fibre with $3 \%$ cement

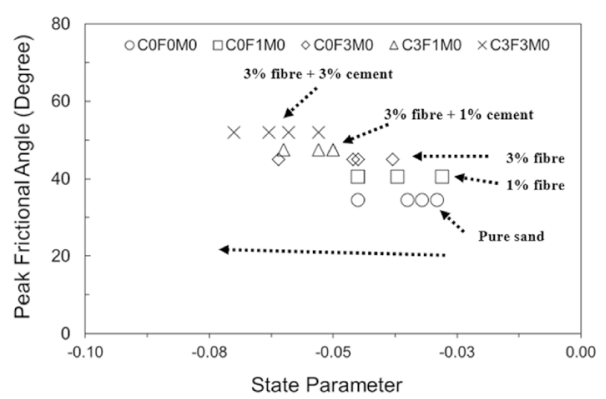

(a) Compression Tests

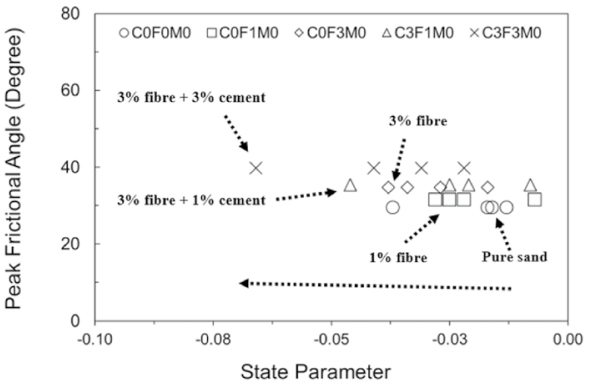

(b) Extension Tests

Fig. 12 Peak frictional angle vs. state parameter from CID compression and extension tests for unreinforced, fibre, and fibre reinforced cemented Toyoura sand specimens $\mathbf{a}$ Compression tests $\mathbf{b}$ Extension tests

tests, the difference is $9-23 \%$ for pure sand and reinforced sand, respectively. Similar results and findings have also been reported for fibre reinforced Hostun RF (S28) sand, [3] and fibre reinforced cemented Toyoura sand [53].

Table 7 summarizes and Fig. 11 shows the slope of the critical state line obtained from the drained tests performed on the unreinforced, fibre reinforced, and fibre reinforced cemented Toyoura sand specimens. The slope of the critical state line significantly increases with the addition of fibre and cement.

Figure 12a, b show the peak frictional angle versus state parameter from the CID compression and extension tests. It can be seen in Fig. 12a (compression tests) that the pure Toyoura sand has a peak frictional angle of $34^{\circ}$, fibre reinforced specimens have a peak frictional angle of approximately $40-44^{\circ}$, and fibre reinforced cemented specimens have a peak frictional angle of approximately $46-52^{\circ}$. The state parameter for 
pure sand is approximately -0.032 to $-0.045,-0.032$ to -0.065 for fibre reinforced sand, and -0.05 to 0.075 for the fibre reinforced cemented specimens. It can also be observed in Fig. 12b (extension tests) that the pure Toyoura sand has a peak frictional angle of $28^{\circ}$, fibre reinforced specimens have a peak frictional angle of approximately $30-33^{\circ}$, and fibre reinforced cemented specimens have a peak frictional angle of approximately $34-39^{\circ}$. In addition, the state parameter for pure sand is approximately -0.015 to $-0.04,-0.01$ to -0.04 for fibre reinforced sand, and -0.015 to 0.065 for fibre reinforced cemented specimens. Overall, the Fig. 12a, b show that the peak frictional angle increases, and state parameter decreases with the inclusion of fibre and cement additives.

\section{Conclusions}

Three different types of material (e.g. Toyoura sand, polyvinyl alcohol (PVA) fibres, ordinary Portland cement (OPC)) have been employed in this study. Toyoura sand is a Japanese benchmark sand, which is a well-known laboratory test sand. The effects of fibre $(0-3 \%)$ and cement $(0-3 \%)$ additives, on poorly graded, uniform Toyoura sand were examined individually and in combination under consolidated drained compression and extension loading conditions.

The results from the compression tests show an increasing peak and stiffness with increasing pressure. A gradual decrease from peak to post-peak strength was also experienced. In addition, cemented, and fibre reinforced cemented specimens showed relatively stiffer response compared to the pure Toyoura sand specimens. Furthermore, results showed that the peak strength of pure sand have been noticeably increased by the inclusion of fibres and cement additives. The fibre and cement when added alone were found to be least effective in extension loading, but the strength of sand was reasonably improved by the combination of fibre and cement additives with slightly higher percentages of fibre and cement.

The significant increases in the strength of fibre reinforced sand might be attributed to the randomly distributed fibres crossing through the plane of failure and increase in mobilized tensile resistance due to the distortion of fibres during the shearing. Fibres might have a significant ability to withstand tension within the sand specimens without breakage or plastic deformations. In addition, the combination of angularity of sand particles and roughness of fibres might also add to the enhanced fibre reinforced sand behavior. Hence, the strength increases in fibre reinforced sand can be attributed to the frictional interaction between particles and fibres (e.g., interlocking due to micro-striations) and the mobilized tensile resistance due to modulus of fibres.

The inclusion of randomly oriented fibres into artificially cemented sands caused a significant increase in both friction angle (due to highly interlocked clusters) and cohesion (due to artificial cementation and bonding), as well as in the compressive strength for such specimens. Hence, fibres when added in cemented sand can effectively improve the brittle behavior.

Moreover, limited increases in secant modulus were observed with inclusion of only fibre additives, but significant increases were found for cemented and fibre reinforced cemented specimens. The fibre and cement additives also increased the strength 
parameters (frictional angle, cohesion), dilatancy angle, slope of the critical state line, and decreased the state parameter of pure Toyoura sand.

The type and percentage of the fibre and cement additives were chosen based on economic considerations and their field applications. In addition, utilization of fibre reinforced cemented sand can greatly help in solving waste disposal problems and a significant volume of the landfills can be minimized [60-62]. Furthermore, the observed improvements in the mechanical response of these amended materials (e.g., despite the short curing times, $0-3 \%$ fibre and cement contents) suggests that this may be a viable strengthening method for dredged soils, disaster wastes and reclaimed land.

\section{Acknowledgements}

The authors would also like to acknowledge our collaborators, Prof. Dr. Kenichi Sato, Dr. Takuro Fujikawa and their graduate students (Miho Nakamichi, Shintaro Koga and Hiromitsu Shiina) of Fukuoka University, Fukuoka, Japan for providing Toyoura sand and the data for comparison in the current study.

\section{Authors' contributions}

Conceptualization and methodology (MS, TN), investigation and analysis (MS), writing-original draft preparation (MS, TN), writing-review and editing (MS, TN and FS), supervision (TN). Allauthors read and approved the final manuscript.

\section{Funding}

The research project was financially supported by the Western Graduate Research Scholarship at the Department of Civil and Environmental Engineering, Western University, London, Ontario, Canada.

\section{Availability of data and materials}

The necessary data is already provided in the paper.

\section{Code availability}

Not applicable.

\section{Declarations}

Competing interests

The authors declare that they have no competing interests.

\section{Author details}

${ }^{1}$ Earthquake Engineering Center, Department of Civil Engineering, University of Engineering and Technology Peshawar, Peshawar, Pakistan. ${ }^{2}$ Department of Civil and Environmental Engineering, Western University, ON, London, Canada.

Received: 22 December 2020 Accepted: 9 August 2021

Published online: 24 September 2021

\section{References}

1. Gray DH, Al-Refeai T (1986) Behavior of fabric-versus fibre-reinforced sand. J Geotech Eng 112(8):804.820

2. Michalowski RL, Cermak J (2002) Strength anisotropy of fibre-reinforced sand. Comput Geotech 29:279-299

3. Diambra A (2010) Fibre reinforced sands: experiments and modelling. Dissertation, University of Bristol

4. Michalowski RL (1997) Limit stress for granular composites reinforced with continuous filaments. J Eng Mech 123(8):852-859

5. Michalowski RL (2008) Limit analysis with anisotropic fibre-reinforecd soil. Geotechnique 58(6):489-501

6. Schmidt Colin JR (2015) Static and Dynamic Response of Silty Toyoura Sand with PVA Fibre and Cement Additives. Dissertation, Western University, Canada

7. Wood DM, Diambra A, Ibraim E (2016) Fibres and soils: a route towards modelling of root-soil systems. Soils Found 56(5):765-778

8. Ranjan G, Vasan RM, Charan HD (1996) Probabilistic analysis of randomly distributed fibre-reinforced soil. J Geotech Eng 122(6):419-426

9. Casagrande MDT, Coop MR, Consoli NC (2006) Behavior of a fibre reinforced bentonite at large shear displacement. J Geotech Geoenviron Eng. https://doi.org/10.1061/(ASCE)1090-0241(2006)132:11(1505)

10. Bueno BS, Lima DC, Teixeira SHC, Ribeiro NJ (1996) Soil fibre reinforcement: basic understanding. Int Symp Environ Geotechnol 3:878-884

11. Stauffer SD, Holtz RD (1996) Stress-strain and strength behavior of staple fiber and continuous filament-reinforced sand. Transpn Res Rec 1474:82-95

12. Shewbridge SE, Sitar N (1989) Deformation characteristics of reinforced soil in direct shear. J Geotech Geoenviron Eng 115(8):1134-1147

13. Nataraj MS, McManis KL (1997) Strength and deformation properties of soils reinforced with fibrillated fibres. Geosynth Int 4(1):65-79 
14. Wei J (2013) Experimental investigation of the behavior of fibre-reinforced sand. Dissertation, Hong Kong University of Science and Technology, Hong Kong

15. Gray DH, Asce AM, Ohashi H (1983) Mechanics of fibre reinforcement in sand. J Geotech Eng 109(3):335-353

16. Santoni RL, Tingle JS, Webster SL (2001) Engineering properties of sand-fibre mixtures for road construction. J Geotech Geoenviron Eng 127(3):258-268

17. Consoli NC, Casagrande MDT, Coop MR (2007) Performance of a fibre-reinforced sand at large shear strains. Geotechnique 57(9):751-756

18. Maher MH, Gray DH (1990) Static response of sands reinforced with randomly distributed fibres. J Geotech Eng 116(11):1661-1677

19. Michalowski RL, Cermak J (2003) Triaxial compression of sand reinforced with fibres. J Geotech Geoenviron Eng 129(2):125-136

20. Broms, BB (1977) Triaxial Tests with Fabric-Reinforced Soil. Proceedings of International Conference on the Use of Fabric in Geotechnics, Ecole National des Ponts et Chaussees, Paris, France, 3:129-134

21. Saran S, Talwar DV, Vaish US (1978) Some aspects of engineering behavior of reinforced earth. Symposium on soil reinforcing and stabilizing techniques. Sydney, Australia, 40-49

22. Talwar DV, Saran S (1983) Triaxial performance of a reinforced sand. Proceedings of the Indian Geotechnical Conference, Madras, India, 1:13-19

23. Gray DH, Ohashi H (1983) Mechanics of fibre reinforcement in sands. J Geotech Geoenviron Eng 109(3):335-353

24. Fukushima S, Mochizuki Y, Kagawa K (1988) Strength characteristic of reinforced sand in large scale triaxial compression test. Proc Int geotech Symp. https://doi.org/10.1016/0148-9062(90)95183-2

25. Shamsher FH (1992) Ground improvement with oriented geotextiles and randomly distributed geogrid micro mesh. Dissertation, IIT Delhi, India

26. Haeri SM, Hamidi A, Hosseini SM, Asghari E, Toll DG (2006) Effect of cement type on the mechanical behavior of a gravely sand. Geotech Geol Eng 24(2):335-360

27. Consoli NC, Prietto PDM, Ulbrich LA (1998) Influence of fibre and cement addition on behavior of sandy soil. J Geotech Geoenviron Eng 124(12):1211-1214.1

28. Consoli NC, Montardo JP, Prietto PDM, Pasa GS (2002) Engineering behavior of a sand reinforced with plastic waste. J Geotech Geoenviron Eng 128(6):462-472

29. Consoli NC, Casagrande MDT, Prietto PDM, Thorne A (2003) Plate Load test on fibre reinforced soil. J Geotech Geoenviron Eng 129(10):95 1-955

30. Consoli NC, Casagrande MDT, Coop MR (2005) Effect of fibre reinforcement on the isotropic compression behavior of a sand. J Geotech Geoenviron Eng 131(11):1434-1436

31. Consoli NC, Vendruscolo MA, Fonini A, Dalla Rosa F (2009) Fibre reinforcement effects on sand considering a wide cementation range. Geotext Geomembr 27(3):196-203

32. Consoli NC, Cruz RC, Floss MF, Festugato L (2010) Parameters controlling tensile and compressive strength of artificially cemented sand. J Geotech Geoenviron Eng 136(5):759-763

33. Consoli NC, Fonseca AV, Cruz RC et al (2011) Voids/cement ratio controlling tensile strength of cement-treated soils. J Geotech Geoenviron Eng 137(11):1126-1131

34. Diambra A, Ibraim E, Muir Wood D, Russell AR (2010) Fibre reinforced sands: experiments and modelling. Geotext Geomembr 28:238-250

35. Diambra A, Ibraim E, Russell AR, Wood MD (2011) Modelling the undrained response of fibre reinforced sands. Soil Found 51(4):625-636

36. Diambra A, Ibraim E, Russell AR, Wood MD (2012) Fibre reinforced sands: from experiments to modelling and beyond. Int J Numer Anal Method Geomech Publ Online. https://doi.org/10.1002/nag.2142

37. Ibraim E, Diambra A, Russell AR, Wood DM (2012) Assessment of laboratory sample preparation for fibre reinforced sands. Geotext Geomembr 34:69-79

38. Diambra A, Ibraim E (2014) Modelling of fibre-cohesive soil mixtures. Acta Geotech 9:1029-1043. https://doi.org/10. 1007/s11440-013-0283-y

39. Diambra A, Ibraim E (2015) Fibre-reinforced sand: interaction at the fibre and grain scale. Géotechnique 65(4):296308. https://doi.org/10.1680/geot.14.P.206

40. Safdar M (2018), "Monotonic Stress-Strain Behavior of Fibre Reinforced Cemented Toyoura Sand." Dissertation PhD, Western University, London, Ontario, Canada

41. Ladd RS (1978) Preparing test specimens using undercompaction. Geotech Test J ASTM I1 (1):16-23

42. Michalowski RL, Zhao A (1996) Failure of fibre-reinforced granular soils. J Geotech Eng 122(3):226-234

43. Ibraim E, Fourmont S (2006) Behavior of sand reinforced with fibres. Soil stress-strain behavior: Measurement, Modelling and Analysis, Geotechnical Symposium, Rome, March 16-17 (Ling, Callisto, Leshchinsky \& Koseki Eds.) Springer, 807-918

44. Eldesouky HM, Morsy MM, Mansour MF (2015) Fibre-reinforced sand strength and dilation characteristics. Ain Shams Eng J 7(2):517-526. https://doi.org/10.1016/j.asej.2015.06.003

45. Clough GW, Sitar N, Bachus RC, Rad NS (1981) Cemented sands under static loading. J Geotech Geoenviron Eng 107(6):799-817

46. Schnaid F, Prietto P, Consoli N (2001) Characterization of cemented sand in triaxial compression. J Geotech Geoenviron Eng 127:857-868

47. Wang YH, Leung SC (2008) A particulate-scale investigation of cemented sand behavior. Can Geotech J 45(1):29-44

48. Maher MH, Ho YC (1993) Behavior of fibre-reinforced cement sand under static and cyclic loads. Geotech Test J 16(3):330-338

49. Gens A, Nova R (1993) Conceptual bases for a constitutive model for bonded soils and weak rocks. Proceedings Geotechnical Engineering of Soft Rocks-Hard Soils, Anagnostopoulos et al. (eds), Balkema, Rotterdam, 485-494

50. Reddy KR, Saxena SK, Budiman JS (1992) Development of a true triaxial apparatus. Geotech Test J 2(5):89-105

51. Chang T, Woods RD (1992) Effect of particle contact bond on shear modulus. ASCE. Journal of Geotechnical Engineering Division 118(8):1216-1233 
52. Park SS (2009) Effect of fibre reinforcement and distribution on unconfined compressive strength of fibre-reinforced cemented sand. Geotext Geomembr 27(2):162-166

53. Nakamichi M, Sato K (2013) A Method of Suppressing Liquefaction Using a Solidification Material and Tension Stiffeners. An International Conference on Soil Mechanics and Geotechnical Engineering, Paris, France. 1547-1550. https://www.cfms-sols.org/sites/default/files/Actes/1547-1550.pdf.

54. Porbaha A, Shibuya S, Kishida T (2000) State of the art in deep mixing technology: Part III-Geomaterial characterization. Ground Improvement. JISSMGE 43:91-110

55. ASTM Standard (C150/C150M-12) (2011) Standard Specification for Portland Cement. ASTM International, West Conshohocken. https://doi.org/www.astm.org

56. ASTM Standard (D7181-11) (2011) Method for consolidated drained triaxial compression test for soils. ASTM International, West Conshohocken, PA, 2011, https://doi.org/www.astm.org

57. Salah-ud-din (2012) Behavior of fibre reinforced cemented sand at high pressures. Dissertation, University of Nottingham, UK

58. Wang J (2005) The stress-strain and strength characteristics of Portaway sand. Dissertation, University of Nottingham, UK

59. Marri A, Wanatowski D, Yu HS (2010) Drained Behavior of Cemented Sand at High Pressures. The 17th Southeast Asian Geotechnical Conference. Taipei, Taiwan

60. Shukla SK (2017) Basic Description of Fibre-Reinforced Soil. In: Fundamentals of Fibre-Reinforced Soil Engineering. Developments in Geotechnical Engineering. Springer, Singapore. https://doi.org/10.1007/978-981-10-3063-5_2

61. Safdar M, Newson T, Schmidt C, Sato K, Fujikawa T, Shah F (2020) Effect of Fiber and Cement Additives on the SmallStrain Stiffness Behavior of Toyoura Sand. Sustainability 12(24):10468. https://doi.org/10.3390/su122410468

62. Safdar M, Newson T, Schmidt C, Sato K, Fujikawa T, Shah F (2021) Shear wave velocity of fiber reinforced cemented Toyoura silty sand. Geomech Eng Int J 25(3):207-219. https://doi.org/10.12989/gae.2021.25.3.207

\section{Publisher's Note}

Springer Nature remains neutral with regard to jurisdictional claims in published maps and institutional affiliations.

\section{Submit your manuscript to a SpringerOpen ${ }^{\circ}$ journal and benefit from:}

- Convenient online submission

- Rigorous peer review

- Open access: articles freely available online

- High visibility within the field

Retaining the copyright to your article

Submit your next manuscript at $>$ springeropen.com 